\title{
TRAINING IN MEDIATION AS A GUARANTEE OF QUALITY OF THE MEDIATING INSTITUTION
}

\begin{abstract}
After a historical review of the evolution of mediation in Spain, the incidence of mediation in society has been proven, both at Spanish and European level, after the approval of Directive 2008/52 / EC of the European Parliament and of the Council of 21May 2008, on certain aspects of mediation in civil and commercial matters. The consolidation of the mediation is still a pending task in Europe, it is necessary to foster the confidence of society in mediation as a formula for effective and quick management and resolution of the conflicts. This paper analyses the level of sufficiency of the necessary requirements to be a mediator in each of the twentyeight Member States and then, firstly, it verifies its possible link with the fact that the States have promoted or regulated the mediation and, secondly, it verifies its possible link with the number of annual mediations performed by them.
\end{abstract}

KeYwORDs: mediation, training, quality, Directive 2008/52/EC, European Union

\section{INTRODUCTION}

Mediation, understood in its updated and professional version, is living in Spain its youth stage: it grows is rising modestly and slowly, it is taking shape, but we still have to dedicate efforts to make it mature, to be consolidated.

Knowing the past of the mediation and its historical evolution situates us and helps us to better understand the current moment. In Spain, mediation, particularly family mediation, began to be discussed in the 1980s. Throughout the 90s, pioneering experiences in family mediation were developed in 
different locations of the Spanish geography, both in the public sector and from the social initiative. After the experience of France and Great Britain who regulated family mediation in the years 1995 and 1996 respectively, and the Recommendation adopted by the Committee of Ministers of the Council of Europe on 21 January 1998 in which the governments of the Member States are urged to institute and promote it or, where appropriate, to invigorate the one they already have, in the year 2001 the first autonomic regulations on family mediation emerge. The first, in Catalonia, followed by Galicia and the Valencian Community. According to the preamble of the currently repealed Law 1/2001 of 15 March 2001 on Family Mediation in Catalonia, the implementation of family mediation finds its determining cause in the steep increase in the divorce rate, thereby increasing the marital litigation and the procedural costs, making necessary, therefore, to find the extrajudicial solution of marital conflict. The numbers speak for themselves, according to data from the Statistical Institute of Catalonia, in 2000 there were 31.665 marriages in Catalonia and there were a total of 20.502 divorces and separations. Fifteen years earlier, the number of marriages was almost the same, but the number of divorces and separations registered was almost half compared to the year 2000 .

Neither is a coincidence that the birth of the autonomic laws of family mediation coincides in time with the enactment of autonomous laws regulating de facto relationship. Also in this case, Catalonia was also the first of the autonomous communities to approve, in 1998, its Law of Stable Couple Unions. Still in the absence of a national law on the matter, all the autonomous communities, little by little, have started to join Catalonia. The last of them to do so, Murcia, passed its law in July 2018. These laws entail the recognition of rights and obligations among the cohabitants and therefore, that they can demand them before the courts. Thus, the laws of family mediation in Spain have also been intended to be an instrument to reduce part of the new conflicts that could arise from these laws of de facto relationship, as well as to transfer to this field the beneficial effects that derive from the self-composition of conflicts that mediation entails.

Certainly, Spain was undergoing a process of legislative reform in the area of family law: effective equality between spouses, marriage between persons of 
the same sex and also the new regime of separation and divorce, as, although the commonly known as the Law of the divorce dates 1981, was years later when it began to be noted that the usual processes of separation and divorce became arduous, expensive and slow processes that, far from trying to reduce or solve the emotional stress of the marriage crisis, they even increased it. All this shows us that the autonomic legislator's interest in regulating family mediation is not coincidental, but obeys a social and legal evolution of the legal regime applicable to the family (García Villaluenga, Vázquez de Castro, 2013, pp. 77-80).

At the state level, in an attempt to reduce litigation in the cases of separation and divorce Law 15/2005 of 8 July 2005 is enacted, which modifies the Civil Code and the Law of Civil Procedure in the matter of separation and divorce. The Statement of Motives of the aforementioned Law 15/2005 of 8 July 2005 states that: "In order to reduce the consequences of separation and divorce for all the family members, to maintain the communication and dialogue, and especially to guarantee the protection of the best interest of the minor, mediation is established as an alternative voluntary remedy for resolving family disputes by mutual agreement with the intervention of an impartial and neutral mediator", and its Third Final Disposition establishes the obligation of the Government to carry out a Mediation Bill, saying that: "The Government will send to the Parliament a Mediation Bill based on the principles established in the provisions of the European Union, and in any case in those of voluntariness, impartiality, neutrality and confidentiality and in respect for the mediation services created by the Autonomous Communities “.

The fundamental impulse to mediation comes with the approval of a general regulation of it, the Law 5/2012 of 6 July 2012 on mediation in civil and commercial matters, by which is transposed to the Spanish legal system the Directive 2008/52/EC of the European Parliament and of the Council of 21 May 2008 on certain aspects of mediation in civil and commercial matters. Gradually, mediation has been introduced in different areas and in recent years has displayed a powerful attractive force in professionals of very diverse groups and disciplines. 


\section{Presence of the mediation in Europe}

Having seen the perspective of the implementation of the mediation in Spain, from its principles at the regional level and exclusively oriented to family mediation until its development at national level and in more diverse areas, it is appropriate to mention that the degree of incidence of the mediation in our society continues to be scarce: the incidence of mediation among those who want to dedicate themselves professionally to it is notoriously greater than its impact on society.

What is necessary to do in order to make the incidence of the mediation in Spanish society greater, in order to be strengthened? The answer must include a fundamental point: it is necessary to build trust in mediation as a formula for effective and rapid management and resolution of the conflicts.

Confidence means having faith in the performance of the other, accepting the guarantee offered by its management. Gaining that confidence in mediation also implies trust in the mediator and its specialization. And for this it is necessary to standardize criteria on the figure and professionalism of the mediator as a well-prepared technician.

The Directive 2008/52 / EC already provided the need to achieve mutual trust between the mediators and the society in which they will perform their profession, and therefore in its Considering (16) it determined that: "To ensure the necessary mutual trust (...). Member States should encourage, by any means they consider appropriate, the training of mediators and the introduction of effective quality control mechanisms concerning the provision of mediation services". Further on, the Directive devotes one of its fourteen articles, Article 4, to the quality of mediation. The aforementioned article establishes the following: "Member States shall encourage, by any means which they consider appropriate, the development of, and adherence to, voluntary codes of conduct by mediators and organisations providing mediation services, as well as other effective quality control mechanisms concerning the provision of mediation services". The second part of the same article goes on to say: "Member States shall encourage the initial and further training of mediators in order to ensure that the mediation is conducted in an effective, impartial and competent way in relation to the parties". 
The Directives are a legal instrument used by the European institutions with the main purpose of harmonizing national laws. They establish an obligation of result for the countries of the European Union (in this case, to promote the mediation by ensuring a balanced relationship between it and judicial proceedings), but they leave freedom for each country to decide how to meet the established objective. Thus, each Member State has chosen a path to follow and, as a consequence, mediation has not been developed equally in all of them.

The Directive 2008/52 / EC provided that the Commission had to submit a report on the application of the Directive to the European Parliament, the Council and the European Economic and Social Committee, taking into account the development of mediation in the European Union and the impact of this in the Member States. Till the date, the Commission has submitted two reports, one in August 2016 and another in June 2017. Both reports indicate that, out of the twenty-eight Member States, seventeen encourage or regulate training in their national legislation: Austria, Belgium, Bulgaria, Cyprus, Croatia, Slovakia, Slovenia, Spain, Finland, Greece, Hungary, Italy, Latvia, Lithuania, United Kingdom, Romania and Sweden.

Table 1. Estimated Number of Mediations per Year

\begin{tabular}{|c|c|c|c|}
\hline $\begin{array}{l}\text { Number of } \\
\text { mediations }\end{array}$ & Countries & $\begin{array}{l}\text { Nr. of } \\
\text { countries }\end{array}$ & $\begin{array}{c}\% \text { of } \\
\text { countries }\end{array}$ \\
\hline More than 10000 & $\begin{array}{l}\text { Germany, Italy, } \\
\text { Netherlands, UK }\end{array}$ & 4 & $14 \%$ \\
\hline Between 5000 and 10000 & Hungary, Poland & 2 & $7 \%$ \\
\hline $\begin{array}{l}\text { Between } 2000 \text { and } \\
5000\end{array}$ & Belgium, France, Slovenia & 3 & $11 \%$ \\
\hline Between 500 and 2000 & $\begin{array}{l}\text { Austria, Denmark, Ireland, } \\
\text { Romania } \\
\text { Slovakia, Spain }\end{array}$ & 6 & $21 \%$ \\
\hline Less than 500 & $\begin{array}{c}\text { Bulgaria, Croatia, Cyprus, } \\
\text { Czech Rep., Estonia, } \\
\text { Finland, Greece, Latvia, } \\
\text { Lithuania, Luxembourg, } \\
\text { Malta, Portugal } \\
\text { Sweden }\end{array}$ & 13 & $46 \%$ \\
\hline
\end{tabular}

Source: «Rebooting the Mediation Directive: Assessing the Limited Impact of its Implementation and Proposing Measures to Increase the Number of Mediations in the EU», p. 8. 
However, as it is shown in the following table, which illustrates the estimated number of mediations presented by the Member States per year, this fact has not led to an increase in mediations in those countries. So, as it can be seen here below, practically half of the countries that have promoted or regulated training, specifically eight out of the seventeen, are among the thirteen Member States that have declared having less than 500 mediations per year.

The results of the table confirm the data stated by the Commission in its report of June 2017: the objectives of Article 1 of Directive 2008/52 / EC, namely: promoting the use of mediation and, in particular, achieving "a balanced relationship between mediation and judicial proceedings", have not been achieved, since, in most Member States, mediation is used in less than $1 \%$ of cases brought before the courts.

Of the four countries that declare reaching more than 10000 mediations per year, only Italy reaches more than 200000 mediations per year. The three remaining countries barely exceed 10000 annually. This disconnection between the known benefits of mediation and its current very limited use in the Member States has been named the "EU Mediation Paradox".

These diverse results come from different legislations in the Member States. The striking case of Italy is explained by a legislation that makes it mandatory in certain types of litigation information on mediation procedures to parties that come to trial, and other incentives among which tax benefits were even included. It should be mentioned that in countries with less bulky numbers other frequent actions of family mediation, school mediation, and especially police mediation affect that the number of conflicts that reach mediation by judicial means is lower.

\section{EVALUATION OF THE REQUIREMENTS TO BE A MEDIATOR: A PRESENT OF TRAINING, A FUTURE OF QUALITY}

The EU Mediation Paradox not only has to do with the disconnection between the benefits of mediation and its application rates, but also with the need to ensure training programs for quality mediators. In an extensive survey conducted by the Department of Citizens' Rights and Constitutional 
Affairs of the European Parliament, 816 experts from the 28 Member States, including lawyers and ADR professionals, were asked among many other questions for their general assessment of the requirements to become mediators in their respective countries. Respondents could choose between three response options (insufficient, acceptable, or strong requirements), or they were given the opportunity to specify another opinion. We developed that evaluation in the following table to comment on its results:

Table 2. Evaluation of the adequacy of the requirements to be a mediator.

\begin{tabular}{|c|c|}
\hline $\begin{array}{c}\text { Training requirements estimated } \\
\text { insufficient }\end{array}$ & $\begin{array}{c}\text { Training requirements estimated } \\
\text { acceptable }\end{array}$ \\
\hline Belgium & Germany \\
\hline Cyprus & Austria \\
\hline Slovenia & Bulgaria \\
\hline Finland & Croatia \\
\hline France & Denmark \\
\hline Italy & Slovakia \\
\hline Ireland & Spain \\
\hline Lithuania & Estonia \\
\hline Malta & UK \\
\hline Poland & Hungary \\
\hline Czech Rep. & Latvia \\
\hline Sweden & Netherlands \\
\hline & Portugal \\
\hline & Romania \\
\hline
\end{tabular}

Source: «Rebooting” the Mediation Directive: Assessing the Limited Impact of its Implementation and Proposing Measures to Increase the Number of Mediations in the EU», pp. 166-207.

As we have said before, only seventeen countries have promoted or regulated mediation training. In those Member States where training is not 
regulated, mediation organizations usually provide training on a voluntary basis. We start, therefore, from a different regulation in this aspect of mediation, so the evaluation in the table responds to the same issues but to a different situation by countries.

As can be observed, practically all of the Member States consider the training requirements insufficient or acceptable, and we have focused on them when making the data table and its commentary. Only Greece considers training requirements strong; and in respect of the other State that does not appear in the table, Luxembourg, the answers given by its experts in the whole survey show, according to the Department, numerous problems of interpretation in regard to its law of mediation that preclude the concrete answer to this question.

It can be observed that both columns include countries of the different classifications contained in table 1 on the annual mediations carried out in each of them. In other words, the consideration of training requirements as insufficient or acceptable does not appear related or linked to the number of annual mediations conducted in that country.

Among the countries that consider the training requirements insufficient, there are half of the Member States that did not reach 500 mediations per year (Cyprus, Finland, Lithuania, Malta, Czech Republic and Sweden) and Italy, which exceeded 200 000. And also Poland that was in the second level of table 1 (between 5000 and 10000 mediations), the three countries of the third level between 2000 and 5000 mediations (Belgium, Slovenia and France), and Ireland located in the next level between 2000 and 500 mediations.

Neither the regulation nor the promotion of training in its different regulations is decisive for the assessment set out in this table 2. Of the seventeen countries that had encouraged or regulated mediation training, seven consider the training requirements insufficient, but the rest do not have that same opinion.

The same variety commented among the twelve countries in the first column is also seen among the fourteen countries in the second column, which consider the training requirements acceptable. But we want to mention that they include three States (Spain, Latvia and Great Britain) that, although most of their experts opt for considering them acceptable, there are also 
numerous responses that consider them insufficient, and, on the contrary, also in three of them (Austria, Slovakia and Portugal) we found the reverse situation that many of their experts consider them strong.

We have analysed that the results of the table do not show links with the promotion or regulation of the mediation of the different countries or with the number of annual mediations performed by them. We now emphasize the heterogeneous result of the table in relation to other criteria: there is no geographical classification of north/south or east/west of the Member States, with the economic or cultural issue that this can involve, as well as countries with a mediating tradition, such as UK or France, that in this case have different opinions.

The results of the survey included in the table confirm the generalized consideration of the need for training requirements in mediation. We believe that the unification of mediation legislation, regulation on training in it, and criteria to evaluate its quality would benefit the application of mediation and its results. Quality controls are increasingly necessary in our society, and universities, which direct this training and collaborate with the rest of the institutions, also have the duty to ensure the quality of their training programs. The recommendation of the European Parliament moves in that direction, since, in view of the 2017 report by the Committee on Legal Affairs, the European Parliament includes among its recommendations the request to the Commission to "study the need to develop quality standards at the level of the Union for the provision of mediation services". The first step to achieve this is to ensure the quality of the training programs.

What has the Spanish normative regulated in this regard? In Spain, according to article 11.2 of the aforementioned Law 5/2012, in order to be a mediator it is required to possess "official university degree or higher professional training and have specific training to exercise mediation, which will be acquired through the realization of one or several specific courses". The article determines the obligatory nature of these specific courses being taught by "duly accredited institutions". Notwithstanding this open conception of the formation, with the approval of Royal Decree 980/2013, of December 13,2013 , by which certain aspects of Law 5/2012 are developed, some basic rules are established in order to preserve the objective to provide mediation 
professionals with the appropriate qualification to exercise it. Hence, the Royal Decree regulates, among other issues, the contents of training and the minimum duration of both specific training and continuous training.

Regarding the content, the training must include, at least: the legal framework, psychological aspects, ethics aspects of mediation, as well as issues related to processes and techniques of communication, negotiation and conflict resolution. These are topics of such a generic nature that it should be studied what content would be necessary to include in the training programs to ensure that students acquire the skills and competencies that ensure that their exercise will be developed with professional standards.

As for the duration, the specific training must reach at least 100 hours of effective teaching both theoretical and practical, corresponding to the latter, at least $35 \%$ of the total required. On the other hand, continuous training must have a minimum total duration of 20 hours, of an eminently practical nature, and must be carried out (in one or several training activities) at least every five years.

As shown in the explanation in Table 2, most experts consider that these are acceptable requirements, but many others consider them insufficient. If we establish a comparison with France, a country with a mediating tradition that already regulated in 2003 the training requirements needed to obtain accreditation as a family mediator, family mediators (since the French positive law only requires special training to exercise mediation in this field) must demonstrate a training of 560 teaching hours, with at least 70 hours of practice, plus the subsequent passing of an exam.

In short, in Spain the accreditation of institutions is required and the contents and the minimum duration of the training are regulated ... but it is not enough. It is known that a good mediator, in addition to having professional characteristics, that would have to do with formative and ethical aspects, must meet certain personal characteristics, such as empathy, a conciliatory attitude, an absence of prejudices and judgments, a sense of humour, originality, etc. Since it is not possible to evaluate such personal characteristics, at least and with the primary objective of generating the necessary confidence in mediation, it would be desirable to establish quality assurance systems for training programs. 


\section{Conchusions}

There is a great disparity and divergence between the twenty-eight Member States with regard to the creation, recognition, growth and development of the profession of mediator. Analysing the data regarding the state of mediation in the different Member States contained in the European e-Justice Portal it is shown the little synergy between the different jurisdictions with reference to the establishment of necessary training requirements, quality parameters of the training programs and mediator accreditation systems.

The lack of confidence in the existing mediation both in Spain and, as has been demonstrated, throughout Europe, requires the dissemination of the knowledge about mediation and the benefits that it offers, as well as the unification of the quality criteria of the training programs. It would be useless to promote mediation by enabling, for example, as in the case of Italy, that it became a precondition to access to judicial proceedings for certain disputes if the mediators who attended them were not well prepared. The good preparation of the mediator goes beyond fulfilling or failing to comply with the formal requirements of national legislations, since the effects derived from the observance of these regulations only affect on secondary issues of the mediation procedure.

Thus, as suggested by the Directive 2008/52 / EC, to establish quality standards for training programs - beyond setting minimum general contents and a specific number of training hours - and, therefore, to guarantee the quality of the mediation is a pending task throughout Europe.

\section{References}

Armadans Tremolosa, I., López Solé, E., Viola Demestre, I. (2018). "La construcción pedagógica de los programas universitarios de formación en mediación” en: Fariña, F., Rosales, M., et al. (Coords.), Construcción de paz a través de la mediación: conocimientos y prácticas de una metodología. Pontevedra: Colección CUEMYC n 1, p. 490-502. ISBN 9788488967428.

Azcarraga Monzonis, C., Quinza Redondo, P. (2015). «Mediation in Spain: Novelties Derived from the Boost of the European Legislator». Ius Comparatum-Global Studies in Comparative Law. Vol. 6, p. 693-710. ISSN 2214-6881.

Barona, S. (2013). Mediación en asuntos civiles y mercantiles en España. Valencia: Tirant lo Blanch, p. 236-250. ISBN 9788490333778. 
Bernal, T. (1993). «Primer Programa Público de Mediación Familiar: Resultados 1993». Anuario de Psicología Jurídica 3, p. 43-54. ISSN 1130-0740.

Bernal, T. (1998). La mediación: Una solución a los conflictos de pareja. Barcelona: Colex.

De Luca, A. (2015). «Mediation in Italy: Feature and Trends». Ius Comparatum-Global Studies in Comparative Law. Vol. 6, p. 345-365. ISSN 2214-6881.

De Palo, G., D’urso, L., Trevor, M., Branon, B., Canessa, R., Cawyer, B., Florence, L.R. (2014). «Rebooting' the Mediation Directive: Assessing the Limited Impact of its Implementation and Proposing Measures to Increase the Number of Mediations in the EU». European Parliament, p. 1-207.

Directive 2008/52/EC of the European Parliament and of the Council of 21 May 2008 on certain aspects of mediation in civil and commercial matters.

Esplugues, Mota C. (2013). «El régimen jurídico de la mediación civil y mercantil en conflictos transfronterizos en España tras la ley 5/2012, de 6 de julio». Boletín mexicano de derecho comparado. Vol. 46, p. 165-199. ISSN 0041-8633.

Esplugues, Mota C. (2015). «New Developments in Civil and Commercial Mediation: Global Comparative Perspectives». Ius Comparatum-Global Studies in Comparative Law. Vol. 6, p. 1-88. ISSN 2214-6881.

García Villaluenga, L. (2006). Mediación en conflictos familiares. Una construcción desde el derecho de familia. Madrid: Reus. ISBN 9788429014570.

García Villaluenga, L., Vázquez de Castro, E. (2013). «La mediación civil en España: luces y sombras de un marco normativo». Política y sociedad, Vol. 50, $\mathrm{n}^{\circ} 1$, p. 71-98. ISSN 1130-8001.

Garoupa, N., Jimenez-Rubio, D., Rosales, V. (2016). «Explaining divorce rate determinants: new evidence from Spain». Applied Economics Letters. Vol. 23, p. 461-464. ISSN 1350-4851.

Herrera de las Heras, R. (2017). «La mediación obligatoria para determinados asuntos civiles y mercantiles». Revista para el análisis del derecho $\mathrm{n}^{\circ}$ 1/2017. ISSN-e 1698-739X.

Institut d'Estadística de Catalunya.

Ley 1/2001, de 15 de marzo, de Mediación Familiar en Cataluña. BOE-A-2001-7380.

Ley 15/2005, de 8 de julio, por la que se modifican el Código Civil y la Ley de Enjuiciamiento Civil en materia de separación y divorcio. BOE-A-2005-11864.

Ley 5/2012, de 6 de julio, de mediación en asuntos civiles y mercantiles. BOE-A-2012-9112. 
Merino Ortiz, C., Morcillo Jiménez, J. (2011). «Regulación de la mediación familiar en España. Estado de la cuestión a la luz del Proyecto de Ley de mediación. Reflexiones sobre las posibilidades de mediar y sus límites». Redur 9, p. 165-189. ISSN 1695-078X.

Vázquez de Castro, E. (2012). «La mediación en el marco de la recepción de la directiva 2008/52/CE, sobre mediación en asuntos civiles y mercantiles. La pendiente trasposición en España». Revista Aranzadi de derecho patrimonial no 28, p. 325-345. ISSN 1139-7179. 
